\title{
On the identification of two Brazilian leafhoppers: redescription of Scoposcartula frontaliana comb. nov. and description of the female of $S$. talitae (Hemiptera: Cicadellidae: Cicadellini)
}

\author{
Gabriel Mejdalani ${ }^{1,2} \&$ Rachel Alexandre Carvalho'
}

\author{
${ }^{1}$ Departamento de Entomologia, Museu Nacional, Universidade Federal do Rio de Janeiro. Quinta da Boa Vista, \\ São Cristóvão, 20940-040 Rio de Janeiro,RJ, Brasil.E-mail: mejdalan@acd.ufrj.br; gmejdalani@uol.com.br \\ ${ }^{2}$ Corresponding author.
}

\begin{abstract}
This paper deals with two species of Scoposcartula Young, 1977 that are very similar to each other externally (form and color pattern): S. frontaliana (Metcalf, 1955) comb. nov. (from the state of Bahia, NE. Brazil) and S. talitae Leal, Mejdalani \& Cavichioli, 2005 (from the state of Espírito Santo, SE. Brazil). The former species, previously positioned in Amblyscarta Stål, 1869, is redescribed and a male specimen is selected as the lectotype. The previously unknown female of the latter species is described for the first time. Scoposcartula frontaliana can be distinguished from S. talitae by features of the male and female genitalia. The most remarkable difference is in the male pygofer, which has a conspicuously concave posterior margin in S. frontaliana, whereas it is convex in S. talitae. The posterior margin of the female sternite VII is convex in S. frontaliana, whereas in S. talitae it has a pair of shallow concavities and a median dentiform projection.
\end{abstract}

KEY WORDS. Auchenorrhyncha; Brazil; female genitalia; lectotype; male genitalia; morphology; sharpshooter.

The Neotropical leafhopper genus Scoposcartula Young, 1977 comprises 15 species, including one from SE. Brazil that remains undescribed because it is known only from female specimens. This genus is distributed from Costa Rica to Argentina, with records in Panama, Colombia, Venezuela, Guyana, Brazil, Bolivia, and Paraguay. A comprehensive study on the taxonomy and phylogeny of Scoposcartula was published by LeAL et al. (2009), who pointed out that the presence of a distinct sclerotized line on the female pygofer is a synapomorphy of the genus. In addition to this synapomorphy, the genus can also be recognized by the position of the ocelli, which in Scoposcartula are usually located well behind the anterior eye angles, an uncommon condition among the Neotropical Cicadellini. The reader should consult LeAL et al. (2009), Young (1977), and Rodrigues et al. (2010) for additional data on the taxonomy, phylogeny, and distribution of Scoposcartula and its species.

Germar (1821) described Tettigonia frontalis based on material from Brazil. Metcalf (1955) recognized that the specific epithet proposed by Germar was preoccupied and, thus, proposed a new name, frontaliana. MetCalf (1955) transferred this species to the Neotropical genus Amblyscarta Stål, 1869. This placement was followed by Young (1977) in his comprehensive monograph of the New World Cicadellini. Neither Metcalf nor Young studied syntypes of $A$. frontaliana, which are housed in the Museum für Naturkunde der Humboldt-
Universität in Berlin. During a study of the digital images of Amblyscarta species on the internet site Sharpshooter Leafhoppers of the World (WiLson et al. 2009), we noticed a remarkable similarity in the shape, size, and color pattern between the photographs of two syntypes of $A$. frontaliana (from the state of Bahia, NE. Brazil) and a species of Scoposcartula, S. talitae Leal, Mejdalani \& Cavichioli, 2005 (from the state of Espírito Santo, SE. Brazil). After borrowing and analyzing the syntypes of $A$. frontaliana, we were able to confirm our suspicion that $A$. frontaliana belongs in Scoposcartula. We also confirmed our initial observation that $A$. frontaliana is externally very similar to $S$. talitae. The two species, however, can be easily distinguished by characters of the male genitalia.

In the present paper, we transfer $A$. frontaliana to Scoposcartula, redescribe this species based on the type series, and select a male syntype to be the lectotype. We also describe the previously unknown female of $S$. talitae. The most relevant characters for distinguishing between the two species are discussed.

\section{MATERIAL AND METHODS}

Techniques for preparation of male and female genital structures follow Oman (1949) and Mejdalani (1998), respectively. The dissected parts are stored in microvials with glycerin and attached below the specimens, as suggested by Young 
\& BeIRne (1958). The morphological terminology follows Young (1977), except for the facial areas of the head (HamiLton 1981, Mejdalani 1998) and the female genitalia (Nielson 1965, Hill 1970, LeAL et al. 2009). Use of the term gonoplac (= third ovipositor valvula) and the names for the processes of the dorsal and ventral sculptured areas of the first ovipositor valvula follow Mejdalani (1998). The photographs of the second ovipositor valvula were taken with a digital camera attached to an optical microscope.

The specimens studied herein belong to the Museum für Naturkunde der Humboldt-Universität (ZMHB; Berlin), Museu Nacional, Universidade Federal do Rio de Janeiro (MNRJ; Rio de Janeiro), and Departamento de Zoologia, Universidade Federal do Paraná (DZUP; Curitiba). Label data are given inside quotation marks with a reversed virgule $(\backslash)$ separating lines on the labels and a semicolon separating different labels of a specimen.

\section{TAXONOMY}

\section{Scoposcartula frontaliana (Metcalf) comb. nov. Figs 1-7}

Tettigonia frontalis Germar, 1821: 64 [preoccupied]

Amblyscarta frontaliana Metcalf, 1955: 264 [nom. nov. pro Tettigonia frontalis Germar, 1821, nec Tettigonia frontalis Donovan, 1798].

This species was catalogued by Metcalf (1965) and McKameY (2007).

Description. Male lectotype. Length, 12.4-12.5 mm ( $\mathrm{n}=$ 2, lectotype and additional specimen).

Head (Figs 1 and 2) moderately produced anteriorly; median length of crown about one-third interocular width and one-fourth transocular width; anterior margin broadly rounded in dorsal view; without carina at transition from crown to face; ocelli located behind line between anterior eye angles, each ocellus distinctly closer to adjacent eye angle than to median line of crown; crown convex with depression on lateral portions between eye and ocellus; without median fovea and without sculpturing or setae; frontogenal sutures extending onto crown and attaining ocelli; antennal ledges not protuberant, in lateral view with anterior margin oblique and convex; frons convex, not flattened medially, with distinct muscle impressions; epistomal suture complete; clypeus with upper half continuing profile of frons, forming distinct angle with nearly horizontal lower half, apical margin convex.

Thorax (Figs 1 and 2) with pronotal width approximately equal to transocular distance; lateral pronotal margins slightly convergent anteriorly, posterior margin almost rectilinear; posterior $2 / 3$ of pronotal disc distinctly striate; dorsopleural carinae complete (lectotype) or incomplete (additional specimen), declivous anteriorly. Mesonotum with scutellum not striate. Forewings (Fig. 1) with veins distinct; with four apical cells, base of fourth more proximal than base of third; with three closed anteapical cells; membrane distinct, including apical cells, apical portions of brachial and anteapical cells, and distal costal area. Hindwings with vein $\mathrm{R}_{2+3}$ incomplete. Hindlegs (lectotype) with femoral setal formula 2:1:1 (2:1:1:1 on the right side of additional specimen); length of first tarsomere slightly greater than combined length of two succeeding tarsomeres; first tarsomere with two parallel rows of small setae on plantar surface.

Color (Figs 1 and 2). Ground color of crown, pronotum, and mesonotum dark brown to black; lateral portions of pronotum (lectotype) with two brownish-white, transversely aligned maculae, outer macula larger than inner one (or with single pair of small maculae in additional specimen). Forewings dark red with three transverse, elongate white maculae: basalmost macula extending from basal half of clavus to near costal margin, median macula extending from distal half of clavus to near costal margin, distalmost macula extending from apex of brachial cell to outer margin of outer anteapical cell; forewing membrane amber. Face and lateral portions of thorax mostly dark brown to black; large macula on median superior portion of frons, large macula on lateral pronotal lobe, and most of mesepimeron, brownish-white; rostrum and legs yellowish-brown to brown. Abdomen mostly red; genitalia dark brown to black with ventral margin of pygofer red.

Genitalia. Pygofer (Fig. 3), in lateral view, well produced posteriorly, subrectangular, just slightly narrowed toward apex; posterior margin distinctly concave; macrosetae distributed mostly on posterior third of disc, extending slightly anteriorly on ventral portion; without pygofer processes. Subgenital plates (Fig. 4), in ventral view, triangular, distinctly narrowed on median third, not fused to each other basally, not extending as far posteriorly as pygofer apex; with uniseriate macrosetae along outer margin. Connective (Fig. 5), in dorsal view, T-shaped; stalk distinctly longer than arms, extending farther posteriorly than styles, directed dorsally and rightward (asymmetrical, not located on median sagittal plane). Styles (Fig. 5), in dorsal view, with outer median lobe; apical portion curved, digitiform, slightly narrowed apically; apex obtuse. Aedeagus (Fig. 6) symmetrical, compressed laterally, without processes; shaft, in lateral view, simple, spatulate, with convex dorsal margin; with inconspicuous sclerotized projection on distal half of dorsal margin; gonopore located apically. Paraphysis (Fig. 5) articulated to apex of connective, extremely elongate, extending much farther posteriorly than apex of subgenital plates and slightly beyond pygofer apex ventrally, distinctly curved on basal half, asymmetrical, not located on median sagittal plane; formed by single ramus (without smaller branch); apex acute.

Female. Length, $12.4 \mathrm{~mm}(\mathrm{n}=1)$.

Head, thorax, and color similar to those of the abovedescribed male. Mesonotum with scutellum slightly striate. Fore- and hindwings, at rest position, extending well beyond ovipositor apex. One specimen with single pair of small macu- 


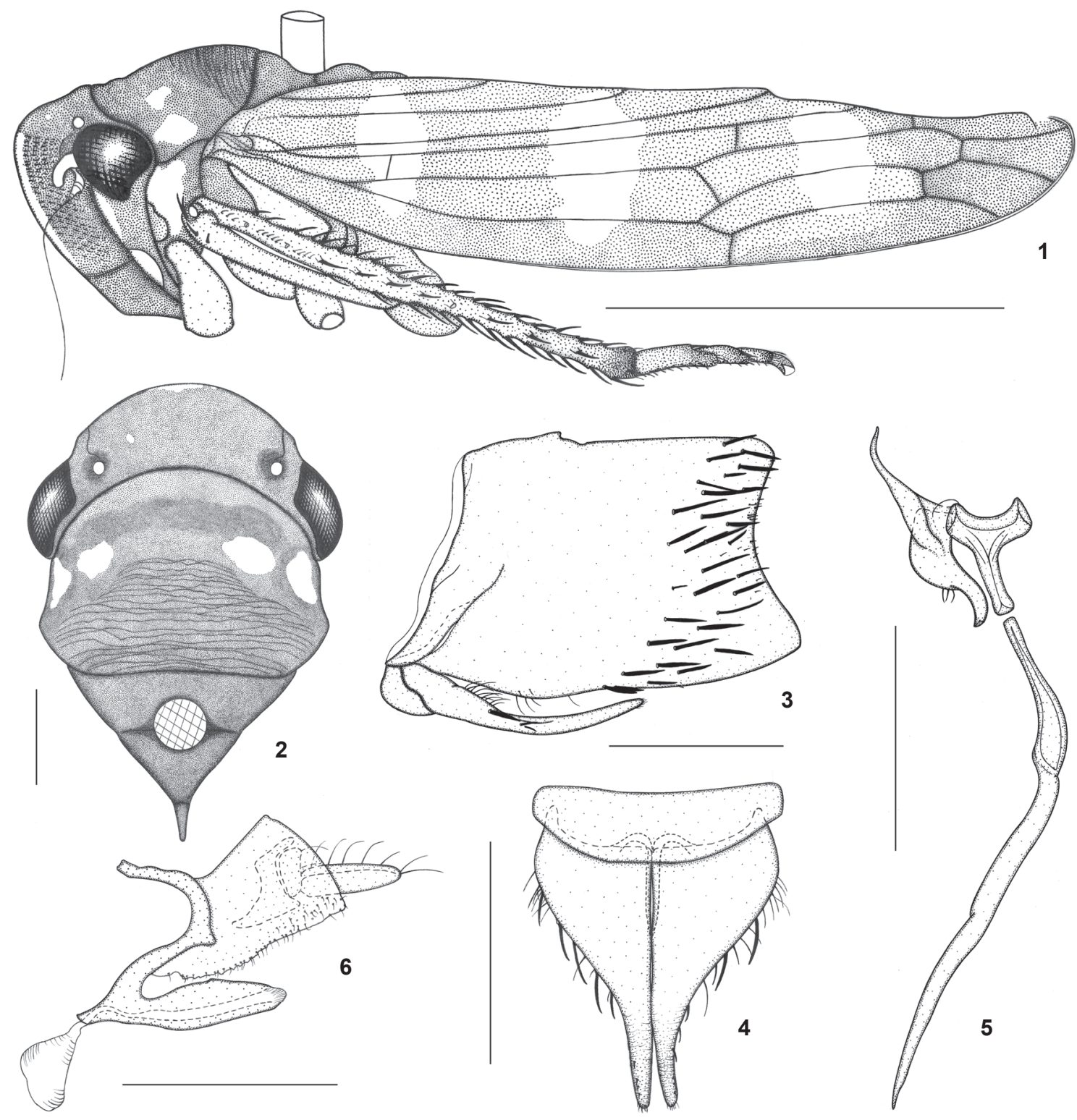

Figures 1-6. Scoposcartula frontaliana comb. nov., male lectotype (position of the pin on the mesonotum is indicated in figures 1 and 2 ): (1) body, lateral view; (2) head, pronotum, and mesonotum, dorsal view; (3-6) genitalia: (3) pygofer, valve, and subgenital plate, lateral view; (4) valve and subgenital plates, ventral view; (5) connective, style, and paraphysis, dorsal view; (6) ejaculatory reservoir, aedeagus, and anal tube, lateral view. Scale bars: $1=5.0 \mathrm{~mm}, 2-6=1.0 \mathrm{~mm}$.

lae on lateral pronotal margins. Abdominal sternite VII (Fig. 7) well produced posteriorly; distal third narrowed, forming distinct median lobe; posterior margin convex, round, without median dentiform projection.

Material examined. Northeastern Brazil, Bahia. Two males, one female: "Bahia $\backslash$ Freire [collector] $\backslash N r .6614$ "; "Syn-Typus?"; "Zool. Mus. \Berlin" (ZMHB). One female, "frontalis $\backslash$ Gm. $\backslash$ Sign.
[SignoRet 1853: 329] pl. 8 fig. 7"; “6614"; "? Type ?\Tettigonia \ frontalis $\backslash$ Germar, 1821"; "[illegible word] \Bahia Freir."; "Amblyscarta \frontaliana n. nov. \Metcalf, 1955"; "Zool. Mus. $\backslash$ Berlin" (ZMHB). One of the males, which was dissected, is here designated as the lectotype (see justification in the discussion below); it received the following label: "LECTOTYPE o' $\backslash$ Amblyscarta $\backslash$ frontaliana $\backslash$ Metcalf, 1955". (An additional fe- 
male type with label "frontalis m. \Brasil." is housed in the collection of the Ivan Franko National University, Lviv, Ukraine; HoLOVACHOv 2008 and Daniela Takiya, personal communication.).

\section{Scoposcartula talitae Leal, Mejdalani \& Cavichioli, 2005}

Figs 8-17

Scoposcartula talitae Leal, Mejdalani \& Cavichioli, 2005: 2.

Description. Female. Length, $11.5 \mathrm{~mm}(\mathrm{n}=1)$.

Head, thorax, and color similar to those of the abovedescribed male of $S$. frontaliana. Mesonotum with scutellum slightly striate. Fore- and hindwings, at rest position, extending well beyond ovipositor apex. Lateroinferior portions of frons and adjacent area of genae with white maculae; with single pair of large white maculae on lateral pronotal portions; distalmost white macula of forewings extending from apex of brachial cell to near costal margin. Hindlegs with femoral setal formula 2:1:1 (left side) or 2:1:1:1 (right side).

Genitalia. Abdominal sternite VII (Figs 8 and 9) well produced posteriorly; distal third not forming distinct median lobe; posterior margin with pair of shallow concavities (emarginations) and median dentiform projection (Fig. 8, DPR); outer (ventral) surface striated on median portion; inner (dorsal) surface with large ridge with approximate form of inverted "V" (convex anteriorly, deeply concave posteriorly), arms of " $\mathrm{V}$ " forming expanded area posteriorly. Internal sternite VIII (Fig. 10), in dorsal view, formed by pair of striated plates located above inverted "V". Pygofer (Fig. 9), in lateral view, moderately produced posteriorly; posterior margin narrowly rounded; dorsomedian portion of pygofer disc with faint sclerotized line (Fig. 9, SCL); macrosetae distributed on posterior third and extending anteriorly along ventral margin. Valvifers I (Figs 1113, VAI), in lateral view, of somewhat trapezoidal form, with lobed projection on posteroventral portion. Valvulae I (Fig. 12, VVI), in ventral view, expanded basally (this expanded portion, in dorsal view, with lobe directed medially); prevalvifer areas (Figs 11 and 12, PVA), in ventral view, with distinct lobe on inner portion of anterior margin and, in lateral view, forming conspicuous process directed dorsally; surface of prevalvifer areas with tiny spiniform tegumentary processes; valvulae I blade, in lateral view, with apical dentiform projection slightly serrated dorsally; dorsal sculptured area (mostly scale-like processes arranged in oblique lines) extending from portion just behind basal curvature to apical portion; ventral sculptured area (scale-like processes) restricted to apical portion; ventral interlocking device (Figs 11 and 12, VID) distinct, elongate, restricted to basal half of blade, located along ventral blade margin but with distal portion directed dorsally. Sclerotized wall (Fig. 11, SWL) located just behind prevalvifer areas, connected to the latter and to valvifers I, with corrugated surface. Valvulae II (Fig. 14), in lateral view, expanded beyond basal curvature; dorsal margin moderately convex with approxi- mately 25 continuous teeth (Fig. 14, TOO); most teeth formed by anterior elevated portion and posterior low flat portion (Figs 16 and 17); first tooth (Fig. 15) distinct from remaining ones, its anterior portion lower than posterior one; denticles distributed on teeth (Fig. 16, DEN) and on dorsal and ventral apical portions (except on apex) of blade (dentate ventroapical portion longer than dorsoapical one); preapical prominence (Fig. 14, PPR) distinct; apex obtuse; valvula with ducts (Fig. 17, DUC) extending into teeth or approaching them, as well as extending toward apical portion. Gonoplacs, in lateral view, abruptly expanded on median portion; expanded portion slightly narrowed apically; apex rounded; surface with tiny spiniform tegumentary processes located mostly on posterior portion and extending anteriorly along ventral margin; some scattered small setae also present.

Material examined. Southeastern Brazil, Espírito Santo. One female: "BR/ES, Santa Teresa \Est. [Estação] Bio. [Biológica] Santa Lúcia \19-23/VIII/2009 \R. Carvalho \& M. Lopes” (MNRJ). One male (holotype): "Santa Teresa/ES $\backslash$ Reserva do Museu $\backslash 16 /$ $\mathrm{X} / 2003 \backslash \mathrm{T}$. T. Mauro col."; "Scoposcartula \talitae ơ \Leal et al., $2005 \backslash$ A. H. Leal det. 2005"; "HOLÓTIPO [holotype]" (MNRJ). One male (paratype): "Parque Sooretama \LINHARES Esp. Santo $\backslash$ Brasil V-1953\P A. Teles Col."; "PARÁTIPO [paratype]"; "Scoposcartula \talitae ơ \Leal et al., 2005 \A. H. Leal det. 2005" (DZUP).

\section{DISCUSSION}

The male genital features clearly indicate that Amblyscarta frontaliana belongs in Scoposcartula. For instance, the connective has the shape of a transverse bar (i.e., it does not bear a median stalk) in Amblyscarta (Young 1977, MejDalani \& Nessimian 1991), whereas in Scoposcartula it has a distinct stalk, so that it can be Y- or T-shaped (Leal et al. 2009). The connective of $S$. frontaliana comb. nov. is clearly T-shaped (Fig. 5). In addition, paraphyses or paraphysis are never present in Amblyscarta (Young 1977), whereas such structures are always well developed in Scoposcartula (LeAl et al. 2009). The genitalia of $S$. frontaliana bear an extremely elongate paraphysis (Fig. 5). Furthermore, the examined specimens fit the detailed description of Scoposcartula provided by Young (1977). The unavailability of males prevented Young (1977) from establishing the proper generic assignment of this species. Since the taxonomy of the Cicadellinae at the generic and specific levels is based primarily on features of the male genitalia, we believe that the selection of a male to be the lectotype of $S$. frontaliana is advisable (see Young 1958 and Young \& Lauterer 1966 for relevant comments on lectotype proposals, the 1966 paper dealing especifically with the Cicadellinae). Unfortunately, the original description (Germar 1821) did not mention the number of specimens examined or their sexes. The type locality (Brazil) given in the original description ("habitat in Brasilia") is in agreement with the label data ("Bahia") of our four specimens. 

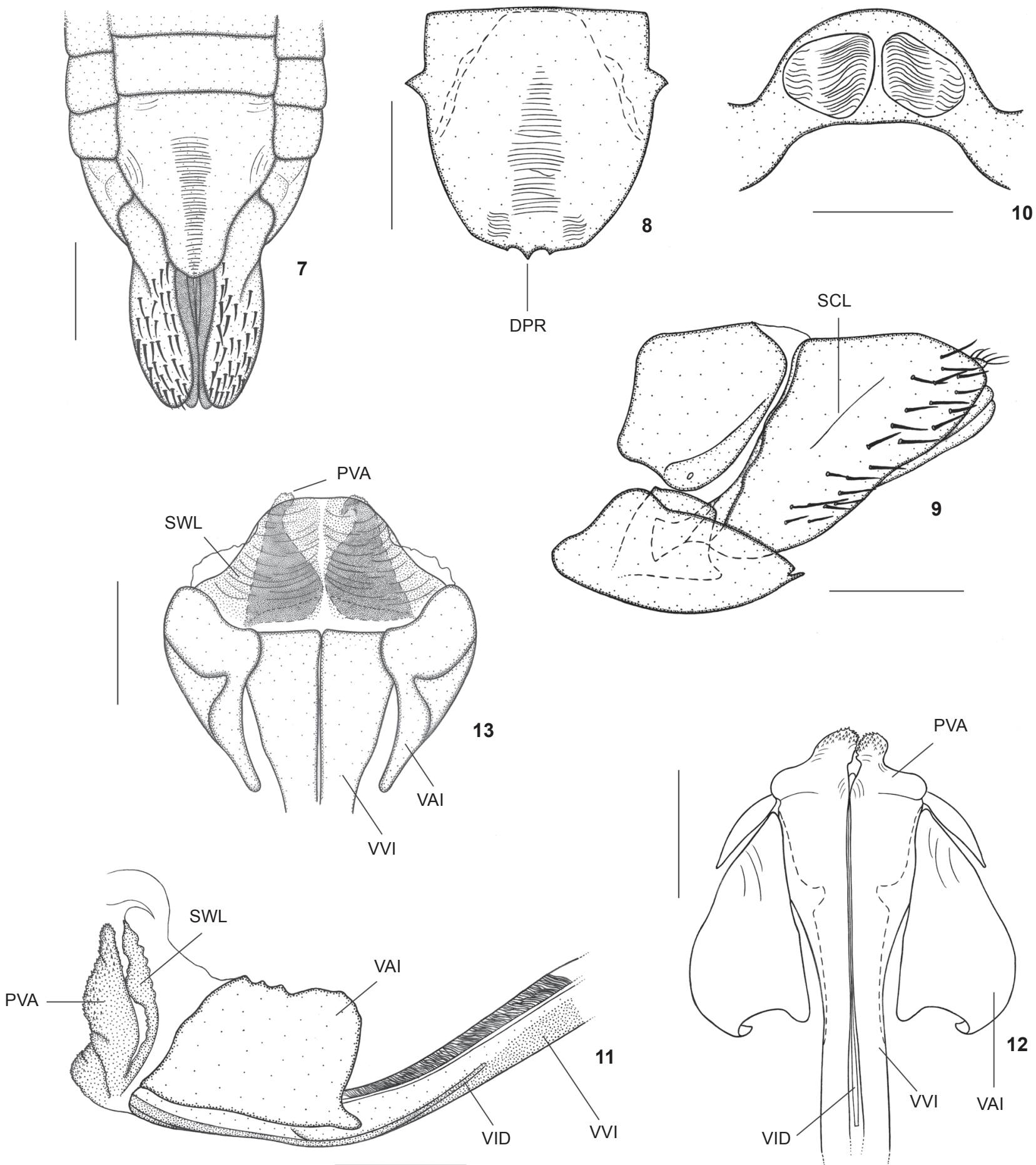

Figures 7-13. Scoposcartula frontaliana comb. nov., female: (7) apical portion of abdomen, ventral view. S. talitae Leal, Mejdalani \& Cavichioli, female: (8) sternite VII, ventral view; (9) apical portion of abdomen, lateral view; (10) internal sternite VIII, dorsal view; (1113) first valvifer, base of first ovipositor valvula, and associated structures in lateral (11), ventral (12), and caudal (13) views. (DPR) Dentiform projection, (PVA) prevalvifer area, (SCL) sclerotized line, (SWL) sclerotized wall, (VAI) valvifer I, (VID) ventral interlocking device, $(\mathrm{VVI})$ valvula I. Scale bars: $7-10=1.0 \mathrm{~mm}, 11-13=0.5 \mathrm{~mm}$. 


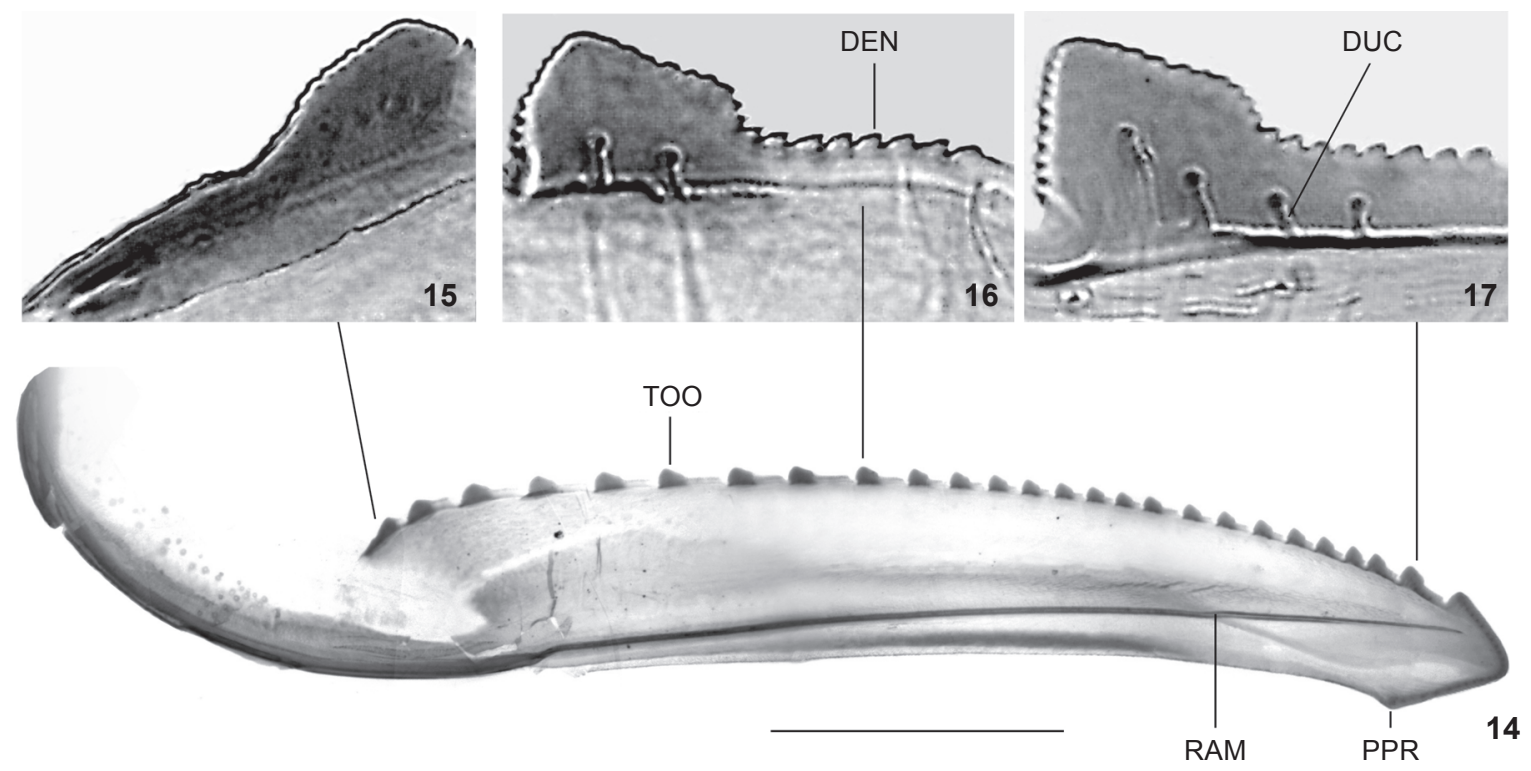

Figures 14-17. Scoposcartula talitae, second ovipositor valvula: (14) general lateral view; (15) first tooth; (16) tooth on median portion; (17) last tooth. (DEN) Denticle, (DUC) duct, (PPR) preapical prominence, (RAM) ramus, (TOO) tooth. Scale bar: $14=0.5 \mathrm{~mm}$.

These specimens were recognized as syntypes by the curator of the Museum für Naturkunde der Humboldt-Universität in Berlin, Dr. Jürgen Deckert (personal communication), based on documentation from the entomological collection. The lectotype and the three additional examined specimens from the type series agree very well with the original description by GERMAR (1821). The Berlin collection has also a male specimen (not examined in the present study) from the state of Pernambuco (NE. Brazil). Its color pattern is similar to that of the type specimens (the white maculae on the dorsum are as in the types but the ground color of the forewings is black instead of dark red; see WiLson et al. 2009). It is not clear whether this specimen belongs to $S$. frontaliana. An additional female type is housed in the Ivan Franko National University (Lviv, Ukraine). We have been able to study high-definition photographs of this female and have found that the shape of the sternite VII (with convex, rounded posterior margin, without median dentiform projection) is in agreement with our present description (Fig. 7), which is based on two females deposited in Berlin. Thus, we believe that the specimen deposited in Lviv also belongs to $S$. frontaliana.

We have not dissected the female genitalia of $S$. frontaliana comb. nov. because the two available specimens are very old and belong to the type series. In the female pygofer of $S$. talitae, a species that is very similar to $S$. frontaliana (see notes below), we have observed the sclerotized line that LeAL et al. (2009) indicated as a synapomorphy of Scoposcartula (Fig. 9, SCL). We hypothesize that the sclerotized line will also be observed on additional female specimens of $S$. frontaliana that become avail- able in the future. The female genitalia of $S$. talitae show the peculiar features observed by LeAL et al. (2009) in other Scoposcartula species: well developed internal sternite VIII (Fig. 10), prevalvifer areas of valvulae I (Fig. 11, PVA), and sclerotized wall (Fig. 11, SWL).

As already stated in this paper, $S$. frontaliana comb. nov. and $S$. talitae are very similar to each other in the external shape and color pattern (they are the only known Scoposcartula species in which the forewings are red with three transverse white stripes). The pronotum bears a single pair of large white maculae in $S$. talitae, whereas in $S$. frontaliana two smaller, transversely aligned maculae may be present on each side (Fig. 2) or just a single small macula. However, the occurrence of intraspecific variation in $S$. frontaliana, which was detected in the small series of specimens available for study, suggests that these pronotal maculae are not reliable for distinguishing the two species. The male genitalia and female sternite VII, on the other hand, offer useful characters for distinguishing $S$. frontaliana from $S$. talitae. In the male genitalia of $S$. frontaliana, the posterior pygofer margin is broad and distinctly concave (Fig. 3), the paraphysis is formed by a single ramus (without a smaller branch) (Fig. 5), and the dorsal margin of the aedeagal shaft is convex (Fig. 6), whereas in S. talitae (Leal et al. 2005) the posterior pygofer margin is distinctly narrower and convex, the paraphysis has a smaller branch, and the dorsal margin of the aedeagal shaft is approximately straight. The sternite VII of the female of $S$. frontaliana is narrowed on the distal third, forming a distinct median lobe, and the posterior margin is simple and convex (Fig. 7), whereas in S. talitae the sternite VII does not 
form a median lobe on the distal third and its posterior margin has a pair of shallow concavities and a median dentiform projection (Fig. 8, DPR).

The female specimen of $S$. talitae herein described was collected in the type locality (Estação Biológica de Santa Lúcia), a 440 ha reserve of Atlantic Forest (dense ombrofilous forest; 550-950 m a.s.l.) in the state of Espírito Santo (EBSL 2011). Unfortunately, we have no precise data on the distribution of $S$. frontaliana comb. nov. in the state of Bahia. The other Scoposcartula species recorded from this state are S. concinna (Perty, 1833), S. furcifera Leal, Mejdalani \& Cavichioli, 2005, and S. oculata (Signoret, 1853) (Leal et al. 2009). Habitat data are also not available for the latter three species. Brief habitat notes have been published only for $S$. tobiasi Cavichioli \& Mejdalani, 1996 and S. flavovittata Mejdalani, 1992. According to Cavichioli \& Mejdalani (1996), S. tobiasi is a common species in the Mantiqueira mountain range (SE. Brazil), occurring at Itatiaia National Park from the inferior altitudinal forest (about $1,500 \mathrm{~m}$ a.s.l.) to areas of transition between the superior altitudinal forest and the alpine field (campo de altitude; about 2,100 $\mathrm{m}$ a.s.l.). Scoposcartula flavovittata, on the other hand, is apparently very rare (only two specimens are known). This species is recorded only from its type locality, a very small spot of forest surrounded by a restinga environment (sand-dune vegetation) at the state of Rio de Janeiro, SE. Brazil (Mejdalani 1992, Cavichioli \& Mejdalani 1996).

\section{ACKNOWLEDGMENTS}

We are greatly indebted to Jürgen Deckert (Museum für Naturkunde der Humboldt-Universität), who has kindly sent us on loan the types of Scoposcartula frontaliana (Metcalf) comb. nov. and provided invaluable information on the Germar collection. Daniela Takiya (Universidade Federal do Rio de Janeiro) has also provided useful information on the Germar collection. Ihor Shydlovskyy (Ivan Franko National University) has kindly sent us high-definition photographs of a female type of S. frontaliana. Márcia Couri (Museu Nacional, UFRJ) allowed us to use the photographic equipment of her laboratory. A fellowship from Conselho Nacional de Desenvolvimento Científico e Tecnológico (CNPq; process number 301391/20114) to GM is acknowledged. The manuscript benefited from the useful comments of two anonymous reviewers.

\section{LITERATURE CITED}

Cavichioli, R.R. \& G. Mejdalani. 1996. Scoposcartula Young: descrições de uma espécie nova e da fêmea de $S$. flavovittata Mejdalani, e redescrição de $S$. concinna (Perty) comb. nov. (Homoptera, Cicadellidae, Cicadellini). Revista Brasileira de Zoologia 13: 963-971.

EBSL. 2011. Estação Biológica de Santa Lúcia. Diagnóstico ambiental. Available online at: http://acd.ufrj.br/ araujo/ ebsl/biologica_diagnosticoambiental.htm [Accessed: 29/X/ 2011].

Germar, E. F. 1821. Bemerkungen über einige Gattungen der Cicadarien. Magazin der Entomologie 4: 1-106.

Hamilton, K.G.A. 1981. Morphology and evolution of the rhynchotan head (Insecta: Hemiptera, Homoptera). Canadian Entomologist 113: 953-974.

HiLL, B.G. 1970. Comparative morphological study of selected higher categories of leafhoppers (Homoptera: Cicadellidae). Ann Arbor, University Microfilms, XI+187p.

Holovachov, O. 2008. Insects of E.-F. Germar in the collections of the Zoological Museum. Available online at: http:// bioweb.lnu.edu.ua/zoo/mus/pages/germar_collection.htm [Accessed: 5/XI/2011].

Leal, A.H.; G. Mejdalani; \& R.R. Cavichioli. 2005. Two new species of the Neotropical leafhopper genus Scoposcartula (Insecta: Hemiptera: Cicadellidae: Cicadellini). Zootaxa 848: 1-9.

Leal, A.H.; G. Mejdalani; R.R. Cavichioli \& R.A. Carvalho. 2009. Taxonomy and phylogeny of the leafhopper genus Scoposcartula (Insecta: Hemiptera: Cicadellidae). Systematics \& Biodiversity 7: 215-233.

McKamey, S.H. 2007. Taxonomic catalogue of the leafhoppers (Membracoidea). Part 1. Cicadellinae. Memoirs of the American Entomological Institute 78: 1-394.

Mejdalani, G. 1992. Uma nova espécie de Scoposcartula Young, 1977 do sudeste do Brasil (Homoptera, Cicadellidae, Cicadellinae). Revista Brasileira de Biologia 52: 231-234.

Mejdalani, G. 1998. Morfologia externa dos Cicadellinae (Homoptera, Cicadellidae): comparação entre Versigonalia ruficauda (Walker) (Cicadellini) e Tretogonia cribrata Melichar (Proconiini), com notas sobre outras espécies e análise da terminologia. Revista Brasileira de Zoologia 15: 451-544.

Mejdalani, G. \& J.L. Nessimian. 1991. Descrição do macho de Amblyscarta stillifera (Stal, 1862) (Homoptera, Cicadellidae, Cicadellinae). Revista Brasileira de Entomologia 35: 307-309.

Metcalf, Z.P. 1955. New names in the Homoptera. Journal of the Washington Academy of Sciences 45: 262-267.

Metcalf, Z.P. 1965. General catalogue of the Homoptera. Fascicle VI, Cicadelloidea. Part 1, Tettigellidae. Washington, D.C., Agricultural Research Service, United States Department of Agriculture, 730p.

Nielson, M.W. 1965. A revision of the genus Cuerna (Homoptera, Cicadellidae). Technical Bulletin of the United States Department of Agriculture 1318: 1-48.

Oman, P.W. 1949. The Nearctic leafhoppers (Homoptera: Cicadellidae). A generic classification and check list. Memoirs of the Entomological Society of Washington 3: 1-253.

Rodrigues, L.G.N.; G. Mejdalani \& R.A. Carvalho. 2010. A new species of Scoposcartula (Hemiptera: Cicadellidae: Cicadellini) with phylogenetic and biogeographic comments on the genus. Zootaxa 2511: 59-68.

SignoRet, V. 1853. Revue iconographique des Tettigonides. Annales de la Société Entomologique de France 1: 323-374. 
Wilson, M.R.; J.A. Turner \& S.H. McKamey. 2009. Sharpshooter leafhoppers of the world (Hemiptera: Cicadellidae subfamily Cicadellinae). Available online at: http://naturalhistory. museumwales.ac.uk/sharpshooters/home.php [Accessed: 19/V/2010].

YounG, D.A. 1958. On lectotype proposals. Systematic Zoology 7: $120-122$

Young, D.A. 1977. Taxonomic study of the Cicadellinae (Homoptera: Cicadellidae), Part 2. New World Cicadellini and the genus Cicadella. Technical Bulletin of the North Carolina Agricultural Experiment Station 239: 1-1135.

Young, D.A. \& B.P. BeIRNe. 1958. A taxonomic revision of the leafhopper genus Flexamia and a new related genus (Homoptera: Cicadellidae). Technical Bulletin of the United States Department of Agriculture 1173: 1-53.

Young, D.A. \& P. Lauterer. 1966. Types of Cicadellinae (Homoptera, Cicadellidae) in the Moravian Museum. Acta Musei Moraviae 51: 261-270.

Submitted: 08.V.2012; Accepted: 05.VII.2012.

Editorial responsibility: Walter A.P. Boeger 